\title{
Process related copper leaching during a combined wood preservation process
}

\author{
Andreas Treu · Erik Larnøy $\cdot$ Holger Militz
}

Received: 9 July 2008 / Published online: 8 April 2010

(C) Springer-Verlag 2010

\begin{abstract}
A combined wood impregnation process including impregnation with a chromium-free wood preservative and oil treatment was evaluated with regard to leaching of copper during the oil process. Two different experimental setups make up the balance of copper content in oil, wood samples and condensate water, also taking different fixation times and process durations into account. Copper is sufficiently fixed after 24 hours, and leaching of copper into the oil is low. Increasing the oil process time does not lead to increased leaching. The hot oil treatment of impregnated wood under vacuum atmosphere is a fast drying method without major negative consequences for the impregnated copper.
\end{abstract}

\section{Prozessimmanente Kupferauswaschung während eines kombinierten Holzschutzverfahrens}

Zusammenfassung Ein kombiniertes Holzimprägnierverfahren, das eine Imprägnierung mit einem chromfreien Holzschutzmittel und eine anschließende Ölbehandlung miteinschließt wurde im Hinblick auf die Kupferausswaschung während des Ölprozesses untersucht. Zwei unterschiedliche Versuchsaufbauten bilanzieren den Kupfergehalt im Öl, in den Holzproben und im Kondensat unter der Berücksichtigung von verschiedenen Fixierungs- und Prozesszeiten. Nach 24 Stunden ist das Kupfer ausreichend

\footnotetext{
A. Treu $(\varangle) \cdot$ E. Larnøy

Section Wood Technology, Norwegian Forest and Landscape

Institute, Pb. 115, 1431 Ås, Norway

e-mail: andreas.treu@skogoglandskap.no

H. Militz

Section of Wood Biology and Wood Products, University

Göttingen, Büsgenweg 4, 37077 Göttingen, Germany
}

fixiert und das Auswaschen des Kupfers in das Öl gering. Längere Prozesszeiten führen nicht zu erhöhten Auswaschmengen. Die Behandlung von imprägniertem Holz in heißem Öl unter Vakuumatmosphäre ist eine schnelle Trocknungsmethode ohne größere negative Einflüsse auf das eingebrachte Kupfer.

\section{Introduction}

The combination of a wood preservative treatment, with subsequent treatment in modified natural oil at elevated temperature was developed some 25 years ago (Häger 1980). It is usually referred to as the "Royal Process". Only recently there has been increasing interest in this technique from both the scientific and commercial side (Powell 2003). The focus from governments on the side effect of CCA- (chromium, copper and arsenic) based wood preservatives has induced restrictions concerning the use of chromium and arsenic. The wood preservatives with the widest distribution in Europe are copper-based products. As copper based preservatives have a higher leaching rate (Humar et al. 2005) than the traditional CCA, discussion about the use and a better fixation of copper in wooden products arose. Wood preservation by combined processes including wood preservative treatment and subsequent impregnation with an hydrophobic product reduces the leaching of copper in use (Treu et al. 2003). Treatment with an hydrophobic product is often performed by using hot oil, which serves the purpose of drying the wood after impregnation with a wood preservative from an almost wet state to a wood moisture content of 12-20\% and obtaining an hydrophobic surface in order to reduce water uptake and decrease leaching of wood preservatives in later use. In addition, crack development and water uptake 
during outside exposure can be reduced, and surface properties can be improved by adding pigments to the oil.

The second step of a combined impregnation process can influence the properties of a product gained in the first step of the process. One important factor of process optimisation is to assure a sufficient amount of wood preservative content in wood during the entire process. Depending on the fixation of copper, after the wood preservative treatment, constituents of the wood preservative can be leached into the surrounding oil.

This paper describes the leaching parameters of copper in a combined process with regard to fixation time and process duration. The influence of different copper fixation times on the leaching of copper into oil during a hot oil treatment was evaluated. The amount of copper in oil, wood samples and condensate water was therefore analysed. Furthermore, the influence of different process durations of the hot oil process on the copper leaching was investigated. This study evaluates the influence of a second step in a wood protection process which is industrially used and answers the question whether this step is disadvantageous for the first impregnation step or not.

\section{Materials and methods}

The combined impregnation process (CIP) includes a twostep process. The first step is a simplified impregnation procedure ("Lowry process") with a copper-based chromiumfree wood preservative (CFWP). The chromium free wood preservative (CFWP) used was a $4 \%$ copper/copper-HDO solution with $13.04 \%$ copper (copper hydroxide carbonate), $2.80 \% \mathrm{Cu}-\mathrm{HDO}$ (bis-( $N$-cyclohexyl diazeniumdioxy) copper), and $4.0 \%$ boric acid. The process parameters for this step are a 1 hour pressure phase (0.9-1.2 MPa) and a $20 \mathrm{~min}$ vacuum $(0.01 \mathrm{MPa})$ at the end of the process. This process was chosen in order to yield good penetration throughout the tissue and a preservative coating on the lumen-side cell wall surface, while leaving the cell lumina empty. The solution uptake is generally significantly lower compared to a usual full cell process.

In the second step of the CIP, conducted in another vessel, the wood samples are treated with hot modified oil (Mod.L.) in a vacuum $\left(80^{\circ} \mathrm{C}, 0.01 \mathrm{MPa}\right)$. The oil is based on a linseed oil, is of brown-yellow colour and hardens within some days. The oil becomes unclear when mixed with water, which happens when several combined treatments with wet wood are performed. Heating up the oil over the boiling point of water for several hours helps to remove the water.

Two tests were performed; one in a small lab-scale plant (Test A) and one in a larger dimensioned pilot plant (Test B).

\subsection{Test A}

CFWP-impregnated Scots pine (Pinus sylvestris) samples with dimensions of $25 \times 115 \times 100 \mathrm{~mm}^{3}$ were end-sealed with Tivosan TR 6030 (Sika Tivoli $\mathrm{GmbH}$ ) and treated for eight hours in a small impregnation device (capacity 7.5 litres) (Table 1). The impregnation device was build for this research in order to simulate principle process parameters with small wood samples. A glass container was connected to a vacuum pump via a cooling trap where water condensates can be collected in a storage device. Samples were stored at room temperature for fixation. The relation between the amount of oil and the unsealed wood surface was $1.73 \mathrm{ml} / \mathrm{cm}^{2}$. The fixation time of wood preservative was 1 , 24,48 , and 120 hours at $20^{\circ} \mathrm{C}$ and $65 \%$ rel. humidity prior to the oil treatment. CFWP-treated control samples had a fixation time of several weeks. The impregnation was performed on Scots pine sapwood samples and with samples that included heartwood and had 40-70\% sapwood. Five sample iterations were used. The average uptake (Stdv) of wood preservative was $13.3(1.5) \mathrm{kg} / \mathrm{m}^{3}$ for sapwood and 9.5 (2.6) $\mathrm{kg} / \mathrm{m}^{3}$ for samples with $40-70 \%$ sapwood (Table 2).

After treatment, the samples were ground in a DIETZmill to chips of 1-2 mm, digested according to AWPA A7-93 (1993) and analysed for their copper content using Flame Atomic Absorption Spectrometry (FAAS) according to DIN 38406-7 (1991). CFWP-treated samples which were stored for fixation at room temperature for several days and which were not undergoing a hot oil treatment were used as controls. Furthermore, the oil and condensate water were analysed for copper content after treatment. FAAS was used for the analysis of copper in oil and condensate.

The condensate water is a result of the drying process in hot oil under vacuum where water is evaporating out of the wood samples.

\subsection{Test B}

CFWP-impregnated and end-sealed Scots pine samples with dimensions of $25 \times 115 \times 800 \mathrm{~mm}^{3}$ and with an average sapwood content of $20 \%$ were treated for 2,5 , and 8 hours in hot oil at $80^{\circ} \mathrm{C}$ after a fixation time of 24 hours at room temperature (Table 1). The average uptake (Stdv) of wood preservative was $8.4(3.9) \mathrm{kg} / \mathrm{m}^{3}$.

Ten treatments, each with eight wood samples and 70 litre of oil, were performed per process time. The relation between the amount of oil and the unsealed wood surface was $3.91 \mathrm{ml} / \mathrm{cm}^{2}$ (Table 2). Overall, 80 samples per process time were oil-treated. After the 1st, 10th, 20th, and 30th oil treatment 1 litre of oil was removed and analysed for its copper content as described above.

The analysed copper content in oil was related to the initial copper content of the wood specimens after impregna- 
tion with the wood preservative. The degree of fixation was calculated according to (1). Furthermore, a fixation index was calculated, taking the maximum fixation degree into account, see (2) (Schoknecht et al. 2003).

$\mathrm{FD}=\frac{\mathrm{U}-\mathrm{L}}{\mathrm{U}} \cdot 100[\%]$

where: $\mathrm{FD}=$ degree of fixation [\%]; $\mathrm{U}=$ average uptake of copper and potential amount of leachable copper $\left[\mathrm{kg} / \mathrm{m}^{3}\right]$; $\mathrm{L}=$ leached out copper in oil related to the amount of wood $\left[\mathrm{kg} / \mathrm{m}^{3}\right]$.

$\mathrm{FI}=\frac{\mathrm{FD}_{t}}{\mathrm{FD}_{\max }} \cdot 100$

where: $\mathrm{FI}=$ Fixation index; $\mathrm{FD}_{t}=$ mean fixation degree at time $t ; \mathrm{FD}_{\max }=$ maximum fixation degree.

The copper content of treated wood samples was not analysed in test B. Nor was the copper content in the condensate water due to an uncertain amount of copper that could be leached out of the material of tubes and condensator.

\section{Results}

\subsection{Test A}

Analysing the copper content of wood samples from test A consisting only of sapwood after different fixation times of CFWP showed that the mean of CFWP control had a significant statistical difference to the 5 days fixation when Tukey-Kramer test and one-way ANOVA analysis is performed (see Fig. 1). Therefore, there is no strong statistical evidence to conclude that the fixation time significantly influences the copper content when different fixation times are compared.
Table 1 Overview of total number, dimension, heartwood proportion and basic density of samples of test A and B

Tab. 1 Übersicht über Anzahl, Abmessung, Kernholzanteil und Basisdichte der Proben aus Versuch A und B

\begin{tabular}{lllll}
\hline & $\begin{array}{l}\text { Total } \\
\text { number } \\
\text { of samples }\end{array}$ & $\begin{array}{l}\text { Sample } \\
\text { size } \\
{\left[\mathrm{mm}^{3}\right]}\end{array}$ & $\begin{array}{l}\text { Heartwood } \\
{[\%]}\end{array}$ & $\begin{array}{l}\text { Basic } \\
\text { density } \\
{\left[\mathrm{kg} / \mathrm{m}^{3}\right]}\end{array}$ \\
\hline Test A & 50 & $25 \times 115 \times 100$ & 0 & $450(30)$ \\
& 25 & $25 \times 115 \times 100$ & $30-60$ & $510(50)$ \\
Test B & 240 & $25 \times 115 \times 800$ & 80 & $470(45)$ \\
\hline
\end{tabular}

No significant statistical difference could be seen from the analysis data of copper content from wood samples including heartwood (40-70\% sapwood). The copper content for all different fixation times was around $1.75 \mathrm{~g} \mathrm{Cu} / \mathrm{kg}$ dry wood for the wood samples including heartwood and around $3 \mathrm{~g} \mathrm{Cu} / \mathrm{kg}$ dry wood for the wood samples consisting only of sapwood.

The copper content of oil samples decreases with increased fixation time. The copper content of oil samples after the treatment of wood samples with a sapwood area of $40-70 \%$ is low after one hour fixation time (Table 3). Already a fixation time of 24 hours strongly reduces the copper content in oil.

A higher copper content in oil was observed after treatment of impregnated sapwood samples not only due to the high amount of copper in sapwood samples, but also due to the increasing crack formation of the samples during the oil process which leads to a deeper oil penetration and thus to a higher leaching of copper. Cracks developed only on some sapwood samples but not on samples that included heartwood.

The copper content of the condensate water that was vaporising out of the samples during the oil process in the lab scale plant of test A and collected in condensate reservoir, is low and even not detectable for the condensate of samples which have $40-70 \%$ sapwood content. The condensate
Fig. 1 Average copper content of ground oil-treated Scots pine wood samples (test A, 8 hour oil treatment) after different fixation times of CFWP (first impregnation set with only sapwood)

Abb. 1 Durchschnittliche Kupfermenge gemahlener, ölbehandelter Kiefernproben (Versuch A, 8-stündige Ölbehandlung) nach unterschiedlichen Fixierungszeiten von CFWP (erstes Imprägnierungskollektiv mit ausschließlich Splintholz)

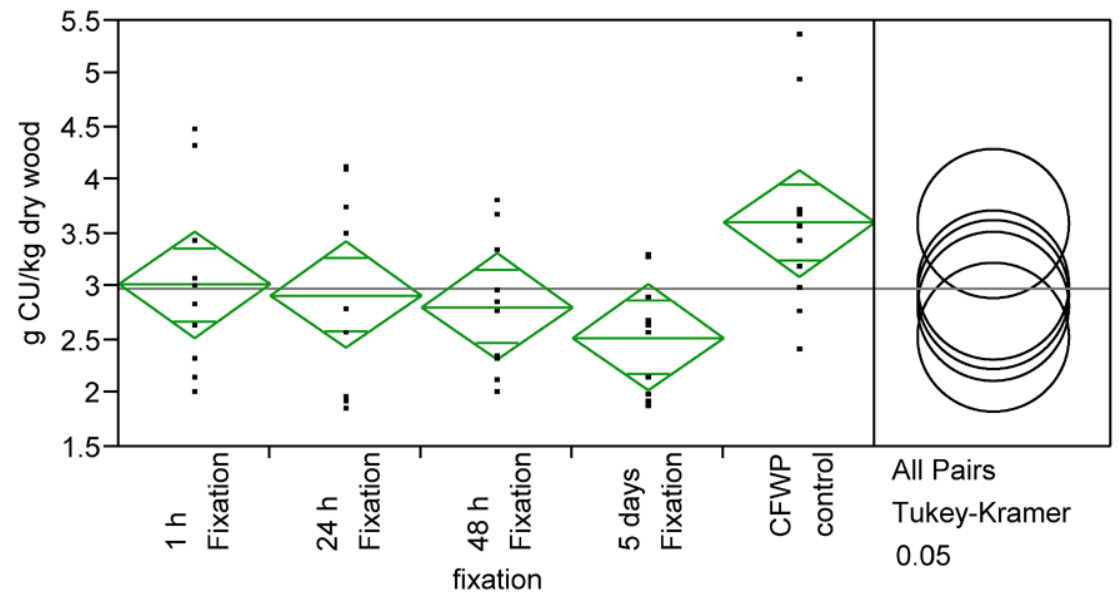




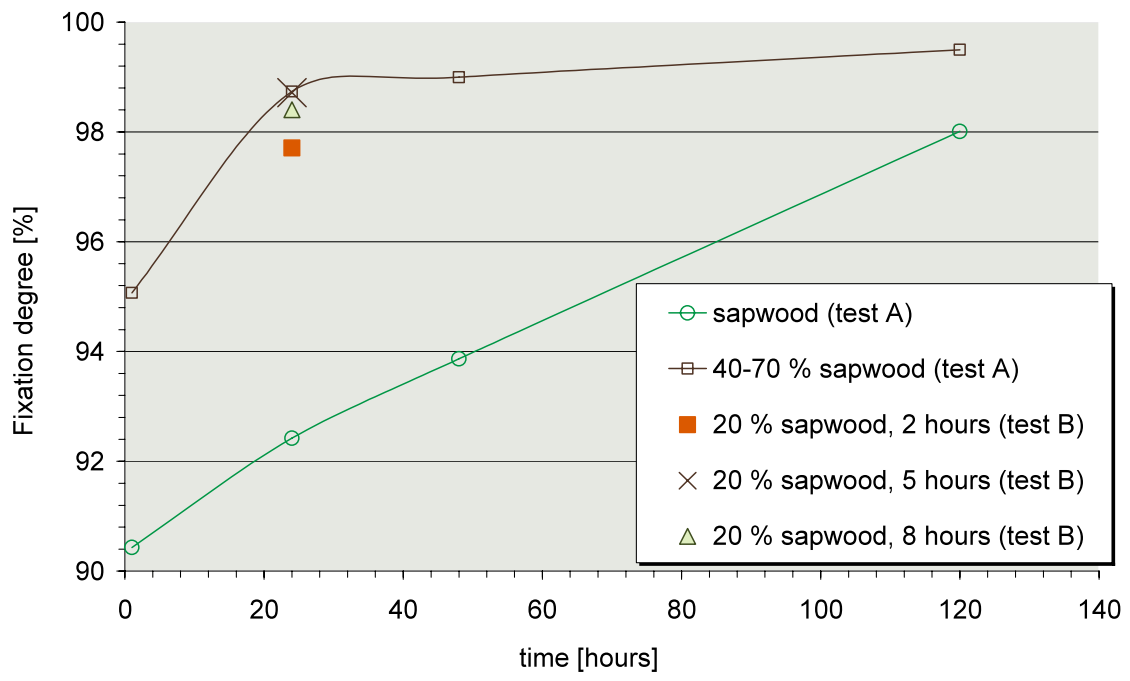

Fig. 2 Fixation degree (FD) of Scots pine samples after one, 24, 48, and 120 hours. The samples of test A were treated for 8 hours in hot oil in a lab scale plant. The samples of test B were treated for 2, 5, and 8 hours, respectively, in hot oil in a pilot plant, after a fixation time of 24 hours Abb. 2 Fixierungsgrad (FD) von Kiefernholzproben nach 24, 48 und 120 Stunden. Die Proben aus Versuch A wurden für 8 Stunden in heißem Öl in einer Laboranlage behandelt. Die Proben aus Versuch B wurden jeweils für 2, 5 und 8 Stunden in heißem Öl in einer Pilotanlage nach einer Fixierungszeit von 24 Stunden behandelt

Table 2 CFWP- and oil uptake, Surface ratio and amount of condensate of test $\mathrm{A}$ and test $\mathrm{B}$ Tab. 2 CFWP- und Ölaufnahme, Oberflächenverhältnis und Kondensatmenge in Versuch A und $\mathrm{B}$

\begin{tabular}{|c|c|c|c|c|}
\hline & $\begin{array}{l}\text { Surface ratio } \\
{\left[\mathrm{ml} / \mathrm{cm}^{2}\right]}\end{array}$ & $\begin{array}{l}\text { CFWP uptake } \\
(\mathrm{Stdv}) \\
{\left[\mathrm{kg} / \mathrm{m}^{3}\right]}\end{array}$ & $\begin{array}{l}\text { Oil uptake } \\
{\left[\mathrm{kg} / \mathrm{m}^{3}\right]}\end{array}$ & $\begin{array}{l}\text { Amount of } \\
\text { condensate } \\
{[\mathrm{ml}]}\end{array}$ \\
\hline Test A (100\% sapwood) & 1.73 & $13.3(1.5)$ & & \\
\hline After $1 \mathrm{~h}$ fixation & & & $143(53)$ & 435 \\
\hline After $24 \mathrm{~h}$ fixation & & & $182(88)$ & 300 \\
\hline After $48 \mathrm{~h}$ fixation & & & $201(64)$ & 192 \\
\hline After $120 \mathrm{~h}$ fixation & & & $263(59)$ & 110 \\
\hline Test A (40-70\% sapwood) & & $9.5(2.6)$ & & \\
\hline After $1 \mathrm{~h}$ fixation & & & $36(3)$ & 269 \\
\hline After $24 \mathrm{~h}$ fixation & & & $57(21)$ & 200 \\
\hline After $48 \mathrm{~h}$ fixation & & & $58(23)$ & 153 \\
\hline After $120 \mathrm{~h}$ fixation & & & $39(19)$ & 76 \\
\hline Test B & 3.91 & $8.4(3.9)$ & & \\
\hline $2 \mathrm{~h}$ & & & $16.4(9.9)$ & 13,082 \\
\hline $5 \mathrm{~h}$ & & & $12.8(9.7)$ & 17,071 \\
\hline $8 \mathrm{~h}$ & & & $9.8(7.8)$ & 18,738 \\
\hline
\end{tabular}

water of sapwood samples leached in oil that were CFWPtreated with a fixation time of 1 hour contained less copper than $0.013 \mathrm{~g} / \mathrm{l}$ condensate or $50 \mathrm{mg} / \mathrm{m}^{2}$ wood.

Calculations showed a high fixation degree (FD) of CFWP-treated Scots pine samples (containing heartwood) after 24 hours. A FD above $90 \%$ was calculated for pure sapwood samples even after no prefixation of CFWP (see Fig. 2).

The results of the amount of copper after different fixation times as well as the analysis of copper in oil and in con- densate water gave an indication for the fixation time used later for trials in the pilot plant (test B).

\subsection{Test B}

Trials with bigger samples $\left(25 \times 115 \times 800 \mathrm{~mm}^{3}\right)$ performed in a pilot plant still display a low amount of copper in oil after different treatment durations (Table 4). Increasing process duration displays no increase in copper leaching. In contrast, longer treatments (five and eight hours, respec- 
Table 3 Copper content analysed in oil gathered after 8 hours of oil treatment of Scots pine wood samples (test A) with different fixation times of CFWP; $\%$ and $\mathrm{g} / \mathrm{l}$ indicates the copper content in oil and $\mathrm{mg} / \mathrm{m}^{2}$ indicates the copper content in oil related to the surface of the treated samples, $0.0025 \%$ copper was detected in fresh oil

Tab. 3 Analysierte Kupfermenge in Öl entnommen nach 8-stündiger Ölbehandlung von Kiefernproben (Versuch A) mit unterschiedlichen Fixierungszeiten von CFWP; \% und g/l beschreibt den Kupferanteil im Öl und mg/m² die Kupfermenge im Öl im Verhältnis zur Oberfläche der behandelten Proben, 0,0025\% Kupfer wurde in frischem Öl analysiert

\begin{tabular}{|c|c|c|c|c|c|c|c|c|c|c|c|c|}
\hline & \multicolumn{3}{|c|}{1 hour fixation } & \multicolumn{3}{|c|}{ 24-hour fixation } & \multicolumn{3}{|c|}{ 48-hour fixation } & \multicolumn{3}{|c|}{ 120-hour fixation } \\
\hline & [\%] & {$[\mathrm{g} / \mathrm{l}]$} & {$\left[\mathrm{mg} / \mathrm{m}^{2}\right]$} & [\%] & {$[\mathrm{g} / \mathrm{l}]$} & {$\left[\mathrm{mg} / \mathrm{m}^{2}\right]$} & [\%] & {$[\mathrm{g} / \mathrm{l}]$} & {$\left[\mathrm{mg} / \mathrm{m}^{2}\right]$} & [\%] & {$[\mathrm{g} / \mathrm{l}]$} & {$\left[\mathrm{mg} / \mathrm{m}^{2}\right]$} \\
\hline $100 \%$ sapwood & 0.0106 & 0.0986 & 1703 & 0.0084 & 0.0781 & 1350 & 0.0068 & 0.0632 & 1092 & 0.0022 & 0.0205 & 353.6 \\
\hline $40-60 \%$ sapwood & 0.0039 & 0.0363 & 626 & 0.0010 & 0.0093 & 160.7 & 0.0008 & 0.0074 & 128.6 & 0.0004 & 0.0037 & 64.3 \\
\hline
\end{tabular}

Table 4 Copper content of oil samples removed respectively after 10 different treatment durations performed in a pilot plant

Tab. 4 Kupfermenge in Ölproben entnommen nach jeweils 10 verschiedenen Behandlungsdauern durchgeführt in einer Pilotanlage

\begin{tabular}{llll}
\hline & {$[\%]$} & {$[\mathrm{g} / \mathrm{l}]$} & {$\left[\mathrm{mg} / \mathrm{m}^{2}\right]$} \\
\hline 10 treatments (two hours) & 0.007097 & 0.066 & 2578.1 \\
10 treatments (five hours) & 0.003978 & 0.037 & 1445.3 \\
10 treatments (eight hours) & 0.004946 & 0.046 & 1796.9 \\
\hline
\end{tabular}

tively) result in lower copper leaching per treatment compared to a two-hour treatment.

In view of the copper leaching values in oil after 24-hour fixation of the samples in test $\mathrm{A}$, the copper leaching values in test $\mathrm{B}$ are comparable if it is considered that the average values of test $B$ are determined after ten treatments.

5- and 8-hour treatment result in a fixation degree above 98\% and the 2-hour treatment slightly below 98\% (see Fig. 2).

\section{Discussion}

Trials in the lab scale plant proved that the impregnated wood samples do not leach a significant amount of copper during the oil treatment after different fixation times. The amount of copper which was analysed in ground samples of test A (Fig. 1) is comparable to the results gained for boards with comparable sapwood content (Scheffler 2002). The copper content of oil samples is maximum four times higher (test A, 100\% sapwood samples) than that measured in fresh oil. For those oil samples gathered after the treatment of Scots pine wood samples containing 40-70\% sapwood (test A), the copper content slightly increases after one hour fixation of the wood preservative compared to the amount of copper in recent oil. A prolonged fixation time of wood preservative in wood samples with low amount of sapwood showed a negligible amount of copper.

The copper content of water condensate of both tests A and $\mathrm{B}$ is even lower and undetectable in some cases in water samples gathered after the impregnation with samples including heartwood. Heartwood is nearly always present in practical dimensions of wood products and was therefore included in the test. Even though it was unlikely to find a high amount of copper in the condensate water, it was necessary to include the condensate water in order to make up the balance.

A suitable test procedure to estimate the fixation time of wood preservatives and impregnation procedures is described by Schoknecht et al. (2003). Copper and Cu-HDO from CFWP, as well as copper and chromium from a preservative containing copper, chromium, and boron (CCB), show a high degree of fixation tested in different impregnation procedures. CFWP-wood preservative therefore requires two days until the fixation index (FI) is larger than 95. It is reported that $\mathrm{Cu}-\mathrm{HDO}$ is fixed by approximately $75 \%$ after 24 hours (Göttsche and Marx 1989). Reference values of 5-10\% for copper leaching and 20-30\% copperHDO leaching from treated wood were also given (Marutzky 1991).

If the fixation index is calculated for the sapwood samples of test $\mathrm{A}$ in relation to a maximum fixation after 120 hours, which showed a fixation degree of $98 \%$, an index of 90.4, 92.4, and 93.9 can be calculated for one hour, 24 hours, and 48 hours fixation, respectively.

It should be mentioned that an 8-hour oil process is harsh for this kind of wood dimension consisting only of sapwood. Several cracks occur during the oil process, which increase the penetration depth and the uptake of oil in the wood sample. This crack development could only be seen at small-dimensioned sapwood samples and does not occur on samples used in other tests or in industrial applications. Due to this deeper oil penetration and the easier accessibility of the wood sample for oil, higher leaching of copper was assumed. Increased FD index values can be calculated for the samples, which contained heartwood and sapwood. The FD after 120 hours of fixation was $99.5 \%$. In relation to this maximum FD after 120 hours, the FI is calculated and showed 95.6, 99.2 and 99.4 for one hour, 24 hours, and 48 hours, respectively. 
Even though the fixation degree is $>90 \%$ after no fixation, the gradient of the FD is changing faster with time in the first 24 hours than after 24 hours.

After a higher number of oil treatments had been performed in the pilot plant (test B), the oil was analysed and compared to the potential amount of leachable copper. The calculation implies that $19 \mathrm{~g}$ of CFWD can be fixed theoretically per sample $\left(0.0023 \mathrm{~m}^{3}\right)$ if an average uptake of $8.4 \mathrm{~kg} / \mathrm{m}^{3}$ is assumed. The copper content in oil is therefore marginal. If the degree of fixation is calculated, it can be stated that $77.1 \%$ were fixed following a two-hour process. A degree of fixation after a five-hour treatment of $87.2 \%$ and $84 \%$ was calculated. These results display a lower copper leaching in oil than those gained in different water leaching tests after different fixation times (Habicht et al. 2003). The total amount of copper leached during different laboratory tests for the most commonly-used ageing methods in Europe (EN 84:1997), the United States (AWPA E11) and Japan (JIS K1571) ranged from 6.3 to $16.1 \%$.

It is assumed that the hot oil treatment improves the fixation of CFWP. The fixation of CFWP at $20^{\circ} \mathrm{C}$ is reported to cause accelerated fixation and higher degrees of fixation compared to fixation at $5^{\circ} \mathrm{C}$, whereas the fixation of $\mathrm{Cu}$-HDO from a Cx-product was similar at $5{ }^{\circ} \mathrm{C}$ and $20^{\circ} \mathrm{C}$ (Schoknecht et al. 2003). Ung and Cooper (2005) found increased fixation rates of different ACQ-treated wood species when conditioned at $50^{\circ} \mathrm{C}$ instead of $22^{\circ} \mathrm{C}$.

The copper in CCA-treated slash pine (Pinus eliiottii) is reported to achieve a $98 \%$ fixation (Jiang et al. 2003). For red pine (Pinus spinosa), a leaching of copper from CCA of 4 to $9 \%$ is observed (Stevanovic-Janezic et al. 2001).

With an average uptake of CFWP of $8.4 \mathrm{~kg} / \mathrm{m}^{3}$, the amount of copper that can be leached out during one oil process averages $0.287 \mathrm{~g} / \mathrm{l}$. After 30 oil treatments a maximum copper amount of $8.61 \mathrm{~g} / \mathrm{l}$ could be obtained if all copper constituents would have leached out. Following a total of 30 oil treatments on 240 wood samples $\left(0.552 \mathrm{~m}^{3}\right)$ $0.149 \mathrm{~g} / \mathrm{l}$ is leached out effectively.

An increased process time does not lead to more copper leaching of the wood samples during the hot oil process (Scheffler 2002). This corresponds to the gained results in the pilot plant (test B). Longer processes lead to a higher drying effect and a greater amount of water is boiling out of the wood samples, which is cooled and collected in the condensate reservoir. It is assumed that a greater amount of process related copper could be detected in the condensate after five and eight hours than after two hours. Increasing the oil process time increases the drying of wood and more water is either collected in the condensator or still mixed with the oil. The water in the oil-water mixture can be released by heating up the oil under vacuum without wood over the vapour pressure of water.

\section{Conclusion}

The fixation time of the CFWP process is desired to be as short as possible, and the subsequent oil process should not have a negative influence on the fixation and should only leach out wood preservative to a limited amount.

It can be concluded from these tests that increased process time of the oil treatment does not lead to a higher amount of copper leaching from the wood samples during the process.

Also it can be concluded, that the hot oil treatment favours the fixation rate of copper and that CFWP is sufficiently fixed since leaching of copper in oil during the oil process is negligible after 24 hours of fixation of CFWP. Even a shorter fixation time results in a high fixation degree ( $>90 \%$ ), but the changing of the FD within the first 24 hours would favour 24 hours of fixation as minimum.

The CIP assures an adequate amount of CFWP in impregnated wood samples. Nevertheless, a certain amount of copper is leached into the oil during the hot oil process. However, the small amount of copper in oil is recirculated and does not leave the process.

The hot oil treatment of impregnated wood under vacuum atmosphere is a fast drying method without major negative consequences for the copper-impregnated product.

The combination of a wood preservative treatment with hot oil treatment leads to a strongly reduced copper leaching of wood products in service. Further improved wood properties given by this combined process are reduced crack development and reduced water uptake during exposure to weathering. Additionally, pigments can be added to the oil, which give various esthetical options and reduce discolouration of the surface.

Acknowledgement The authors would like to thank the financial support given by Dr. Wolman GmbH.

\section{References}

AWPA A7-93 (1993) Standard for wet ashing procedures for preparing wood for chemical analysis

AWPA E11-97 (1997) Standard method of determining the leachability of wood preservatives. American Wood Protection Association

DIN 38406-7 (1991) German standard methods for the examination of water, waste water and sludge; cations (group E); determination of copper by atomic absorption spectrometry (AAS) (E 7)

EN 84 (1997) Wood preservatives - accelerated ageing of treated wood prior to biological testing-leaching procedure. European Standard

Göttsche R, Marx H-N (1989) Kupfer-HDO - ein vielseitiger Wirkstoff im Holzschutz. Holz Roh- Werkst 47:509-513

Habicht J, Häntzschel D, Wittenzellner J (2003) Influence of the fixation and ageing procedures on the leaching behaviour of copper from selected wood preservatives in laboratory trials. The International Research Group on Wood Preservation, Brisbane, Australia, IRG/WP 03-20264 
Häger BO (1980) Process for the treatment of wood. UK patent application, United Kingdom, GB2044311A

Humar M, Kalan P, Šentjurc M, Pohleven F (2005) Influence of carboxylic acids on fixation of copper in wood impregnated with copper amine based preservatives. Wood Sci Technol 39:685-693

Jiang MLJ, Qin D, Wang Y, Jiang Z (2003) Leaching characteristics of copper in copper treated wood. The International Research Group on Wood Preservation, Brisbane, Australia, IRG/WP 03-30316

JIS K1571 (1998) Qualitative standards and testing methods of wood preservatives, Japanese Industrial Standard

Marutzky R (1991) Kesseldruckimprägnierte Hölzer für Spielplatzgeräte: Auswaschungs- und Entsorgungsprobleme. Holz-Zent bl 116:1806

Powell MR (2003) Treatment of wood with royale stabilising oil. In: First European conference on wood modification, 3-4 April 2003, Ghent, Belgium, pp 15-22

Scheffler D (2002) Untersuchung zur Reduzierung der Auslaugung eines kupferbasierten Holzschutzmittels im Royalverfahren mit leinölbehandeltem Kiefernholz. Diploma thesis, Institute of Wood Biology and Wood Technology, University Göttingen
Schoknecht U, Mathies H, Wegner R, Bornkessel C (2003) Gutachten über die Entwicklung eines Prüfverfahrens zur Ermittlung von Mindestfixierzeiten von Holzschutzmitteln [Fixation of wood preservatives]. M. d. L. B. Bundesanstalt für Materialforschung und -prüfung (BAM), Bundesministerium für Umwelt, Naturschutz und Reaktorsicherheit. Forschungsbericht 36004011, UBA-FB 000550 (in German with English abstract)

Stevanovic-Janezic T, Cooper PA, Ung YT (2001) Chromated copper arsenate preservative treatment of North American hardwoods, part 2: CCA leaching performance. Holzforschung 55(1):7-12

Treu A, Militz H, Habicht J, Klaucke R (2003) Kombinationsverfahren von bioziden Holzschutzmitteln und Hydrophobierungsmitteln, 23. In: Holzschutztagung der DGFH, 26-27 March, Augsburg, Germany

Ung YT, Cooper PA (2005) Copper stabilization in ACQ-D treated wood: retention, temperature and species effects. Holz RohWerkst 63:168-191 